REVISÃO / REVIEW

\title{
Models and Applications for Risk Assessment and Prediction of Asian Soybean Rust Epidemics
}

\author{
Emerson M. Del Ponte ${ }^{1}$, Cláudia V. Godoy ${ }^{2}$, Marcelo G. Canteri ${ }^{3}$, Erlei M. Reis ${ }^{4}$ \& X.B. Yang ${ }^{5}$ \\ ${ }^{1}$ Departamento de Fitossanidade, Faculdade de Agronomia, Universidade Federal do Rio Grande do Sul, Cx. Postal 15100,

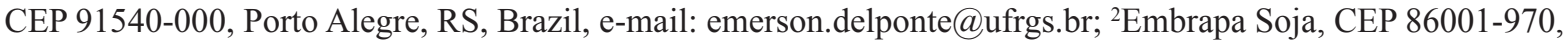 \\ Londrina, PR, Brazil, e-mail: godoy@cnpso.embrapa.br; ${ }^{3}$ Departamento de Agronomia, Universidade Estadual de \\ Londrina, CEP 86051-990, Londrina, PR, Brazil, e-mail: canteri@uel.br; ${ }^{4}$ Universidade de Passo Fundo, \\ CEP 99001-970, Passo Fundo, RS, Brazil, e-mail: erleireis@tpo.com.br; ${ }^{5}$ Department of Plant Pathology, \\ Iowa State University, 50011, Ames, Iowa, USA, e-mail: xbyang@iastate.edu
}

(Accepted for publication 18/12/2006)

Author for correspondence: Emerson Medeiros Del Ponte

DEL PONTE, E.M., GODOY, C.V., CANTERI, M.G., REIS, E.M. \& YANG, X.B. Models and applications for risk assessment and prediction of Asian soybean rust epidemics. Fitopatologia Brasileira 31:533-544. 2006.

\begin{abstract}
Asian rust of soybean [Glycine max (L.) Merril] is one of the most important fungal diseases of this crop worldwide. The recent introduction of Phakopsora pachyrhizi Syd. \& P. Syd in the Americas represents a major threat to soybean production in the main growing regions, and significant losses have already been reported. P. pachyrhizi is extremely aggressive under favorable weather conditions, causing rapid plant defoliation. Epidemiological studies, under both controlled and natural environmental conditions, have been done for several decades with the aim of elucidating factors that affect the disease cycle as a basis for disease modeling. The recent spread of Asian soybean rust to major production regions in the world has promoted new development, testing and application of mathematical models to assess the risk and predict the disease. These efforts have included the integration of new data, epidemiological knowledge, statistical methods, and advances in computer simulation to develop models and systems with different spatial and temporal scales, objectives and audience. In this review, we present a comprehensive discussion on the models and systems that have been tested to predict and assess the risk of Asian soybean rust. Limitations, uncertainties and challenges for modelers are also discussed.
\end{abstract}

Additional keywords: Phakopsora pachyrhizi, disease forecasting, disease simulation models, fungal aerobiology.

\begin{abstract}
RESUMO
Modelos e aplicações de avaliação e previsão de risco de epidemias da ferrugem asiática da soja

A ferrugem Asiática da soja [Glycine max (L.) Merril] é atualmente uma das mais importantes doenças foliares dessa cultura no mundo. A recente introdução de seu agente causal, o fungo Phakopsora pachyrhizi Syd. \& P. Syd, nas Américas representa uma grande ameaça à sojicultura nas principais regiões produtoras do mundo, onde perdas significativas foram relatadas. A ferrugem Asiática da soja é uma doença extremamente agressiva sob condições ambientais favoráveis, causando rápida desfolha nas plantas e danos à produção de grãos. O conhecimento epidemiológico sob condições controladas e naturais, os quais visam elucidar os fatores que afetam os processos do ciclo da doença tem sido fundamental para dar base a estudos de modelagem da epidemia. Devido à importância e recente expansão da doença para as principais áreas de produção de soja no mundo, uma nova atenção tem sido dada ao desenvolvimento, avaliação e aplicação de modelos para avaliação de risco e previsão de suas epidemias, valendo-se de avanços recentes no conhecimento epidemiológico, métodos estatísticos e simulação por computador. O conhecimento gerado tem permitido a construção de novos modelos para a previsão e avaliação de risco de doenças, os quais se diferenciam em relação aos parâmetros estimados, escala espacial ou temporal, objetivo e público alvo. Nesta revisão, é apresentada uma discussão detalhada de modelos e sistemas de previsão e avaliação de risco da ferrugem da soja encontrados na literatura, bem como os desafios, limitações e incertezas nas previsões.

Palavras-chave adicionais: Phakopsora pachyrhizi, previsão de doenças de plantas, modelos de simulação de epidemias, aerobiologia de fungos.
\end{abstract}

\section{Distribution and epidemiological aspects}

Asian soybean rust (ASR) [Glycine max (L.) Merril] is a fungal disease (Phakopsora pachyrhizi Syd. \& P. Syd) of great economic concern to soybean. The first report dates from 1902, in Japan, and during the last century the disease has been reported in several countries in Asia, as well as in India and Australia, causing significant losses (Kitani \& Inoue, 1960, Kochmann, 1977, Bromfield, 1984, Sinclair \& Hartman, 1999). ASR was thought to have spread westerly into Africa in the mid 90's (Levy, 2005). Meanwhile, the 
disease was reported in Hawaii in 1994 (Killgore \& Heu, 1994). From Africa, the fungus was thought to have spread into South America, affecting late-season soybean plants in Paraguay and Brazil in 2001 (Yorinori et al., 2002), and in northern Argentina in 2002 (Rossi, 2003). In November 2004 Asian soybean rust was found in the continental United States, the last major soybean production area where it had not been previously reported (Schneider et al., 2005).

Comprehensive epidemiological studies on Asian soybean rust were initiated in the $70 \mathrm{~s}$ in containment facilities in the United States (Bromfield, 1980), but there have also been studies from Asian countries that examined changes in local epidemics, as well as controlled environment studies (Tan, 1996). Most of these studies aimed to examine environmental and biological factors affecting individual disease cycle components and mechanisms that lead to yield losses (Kitani \& Inouse, 1960, Marchetti et al., 1976, Melching et al., 1979, Tschanz, 1984). In brief, long dew periods and temperatures ranging from $15^{\circ} \mathrm{C}$ to $29^{\circ} \mathrm{C}$ appear to be optimal for soybean rust development (Marchetti et al., 1976, Melching et al., 1989). Rapid disease establishment and development in the field, with devastating effects on yield, has been associated with high rainfall during the growing season (Tschanz, 1984, Tan, 1996). With the recent expansion of Asian soybean rust in the last 10 years, further epidemiological studies on single disease cycle components have been done in countries where it has recently been found. For example, controlled-environmental studies in Brazil have shown that the optimal temperature for fungal germination ranged between 15 and $25^{\circ} \mathrm{C}$, with a minimum wetness period of 6 hours required for infection, and increasing infection efficiency with 8 to 12 hours of wetness duration (Alves et al., 2006a). Moreover, the latent period was a function of temperature, with the shortest period occurring below $23{ }^{\circ} \mathrm{C}$ (Alves et al., 2006b). In South Africa, studies showed that no rust development occurred for temperatures equal to or less than $15^{\circ} \mathrm{C}$ and equal to or greater than $30{ }^{\circ} \mathrm{C}$ after infection, and for temperatures that were within this range, lesion size was increased when air relative humidity was $95 \%$, compared to $85 \%$ (Caldwell, 2005). Studies for the relationship between urediniospore viability and exposure to solar radiation, investigated under field conditions in Paraguay, showed that the proportion of $P$. pachyrhizi urediniospores that germinated decreased with increasing exposure to solar radiation, with no germination under daily solar radiation doses $\geq 27.3 \mathrm{MJ} / \mathrm{m}^{2}$ (Isard et al., 2006).

\section{ASR Model types and applications}

Plant disease forecasting models, usually referred to as prediction or disease risk models, have been developed based on the epidemiological knowledge obtained from controlled environment or field studies. Yang (2003) outlined the use of the terms "risk prediction" and "risk assessment", according to the temporal and spatial scale that uses the risk. "Risk prediction" reflects advances in disease risk communication at the farm level for a single season. "Risk assessment" is an epidemiological study to predict future occurrence of a disease by using non-experimental approaches, often through computer modeling. The study in risk assessment is a macroscale, long-term prediction that encompasses assessment of potential for entry, establishment, epidemic, and/or crop losses in a region or country once an epidemic occurs (Yang, 2006). Several mathematical and computer models have been developed for predicting Asian soybean rust epidemics (Yang et al., 1991a, Batchelor et al., 1997, Isard et al., 2005, Del Ponte et al., 2006, Kim et al., 2006, Pivonia \& Yang, 2006) with applicability in risk assessment studies and prediction frameworks. Recently, plant pathologists, in collaboration with climatologists, have paid new attention to the development, testing and application of models to assess the risk and predict ASR. This has been through using both new and re-analyzed data, as well as new methods and technological resources for modeling development and information delivery. Currently, methods and applications for risk estimation vary among different research groups. Differences encompass model type and how climatic, meteorological, phenological, geographical and other relevant data are stored, processed, and delivered to end-users.

ASR models can be classified in two major groups: simulation and empirical models. Simulation (process driven) models are based on concepts derived from a pathosystem and help to improve the understanding of the structure and behavior of such a biological system (Teng, 1985). Empirical models are typically constructed through the statistical relationship(s) of explanatory variables with experimental data. This data may be from the field on individual (e.g. survival, dispersal, infection, latency, sporulation) or combined epidemic components (e.g. disease progress, final severity). Most models use the response of foliar pathogens to the combined effects of temperature and duration of leaf wetness (Duthie, 1997). These models have commonly been used in disease forecasting systems, with the reliability of model predictions heavily dependent on the quality of the dataset used for model development (Krause et al., 1975). Table 1 summarizes information on twelve ASR models found in the literature and that are discussed in this review.

\section{Simulation models}

Simulation ASR models can be separated into two groups: epidemiological and aerobiological models. Simulation epidemiological models aim to mimic biological processes in the disease cycle to estimate disease development considering local inoculum availability. Three models of this kind were found with applicability mostly for risk assessment studies of potential establishment, epidemic development, losses and survival (models 1 to 3, Table 1). Aerobiological models are eventually more complex than the epidemiological ones and aim to predict transport and dissemination of airborne inoculum over long distances. These models are used mainly to assess the entry potential 
Models and apllications for risk assessment and prediction...

TABLE 1 - Mathematical models and their characteristics used for risk assessment and risk prediction of Asian soybean rust epidemics that have been published in the literature

\begin{tabular}{|c|c|c|c|c|c|}
\hline $\begin{array}{l}\text { Model } \\
\text { number }\end{array}$ & $\begin{array}{c}\text { Framework /approach for } \\
\text { model development }\end{array}$ & $\begin{array}{r}\text { Model type } \\
\text { main use }^{2} \\
\end{array}$ & $\begin{array}{c}\text { Epidemic } \\
\text { component (s) }\end{array}$ & Main estimatio $\mathbf{n}(\mathbf{s})$ & $\begin{array}{l}\text { Model name - } \\
\text { reference }\end{array}$ \\
\hline 1 & mechanistic, process-driven & $\mathrm{S}-\mathrm{RP}, \mathrm{RA}$ & $\begin{array}{l}\text { Epidemic and loss } \\
\text { potential }\end{array}$ & $\begin{array}{l}\text { Disease severity } \\
\text { progress }(\%)\end{array}$ & $\begin{array}{l}\text { SOYRUST, } \\
\text { Yang et al., } \\
(1991 \mathrm{a}, \mathrm{b})\end{array}$ \\
\hline 2 & Analytic, process-driven & $S-R A$ & $\begin{array}{l}\text { Establishment } \\
\text { potential }\end{array}$ & $\begin{array}{l}\text { Daily number of } \\
\text { infectious units }\end{array}$ & $\begin{array}{l}\text { Pivonia \& Yang } \\
\text { (2006) }\end{array}$ \\
\hline 3 & CLIMEX $^{6}$ & S - RA & Survival potential & $\begin{array}{l}\text { Disease stress -free } \\
\text { index }(0-1)\end{array}$ & $\begin{array}{l}\text { Pivonia \& Yang } \\
\text { (2004) }\end{array}$ \\
\hline 4 & HYSPLIT $^{4}$ & $\mathrm{~S}-\mathrm{RA}, \mathrm{RP}$ & Entry potential & $\begin{array}{l}\text { Spore dispersal and } \\
\text { concentration }\end{array}$ & Pan et al. (2005) \\
\hline 5 & HYSPLIT & S - RA & Entry potential & $\begin{array}{l}\text { Spore availability index } \\
(0-7)\end{array}$ & Kim et al. (2005) \\
\hline 6 & HYSPLIT & $\mathrm{S}-\mathrm{RP}$ & $\begin{array}{l}\text { Entry and } \\
\text { establishment } \\
\text { potential }\end{array}$ & $\begin{array}{l}\text { spore dispersal, } \\
\text { qualitative disease risks }\end{array}$ & $\begin{array}{l}\text { NAPDFC } \\
(2006)\end{array}$ \\
\hline 7 & $\begin{array}{l}\text { Aerobiological process - } \\
\text { driven }\end{array}$ & $\mathrm{S}-\mathrm{RA}, \mathrm{RP}$ & $\begin{array}{l}\text { Entry, } \\
\text { establishment and } \\
\text { epidemic potential }\end{array}$ & $\begin{array}{l}\text { Spore dispersal and } \\
\text { disease development }\end{array}$ & $\begin{array}{l}\text { SRAPS }^{3} \\
\text { Isard et al. } \\
(2005)\end{array}$ \\
\hline 8 & Non-linear regression & $E-R P$ & Infection potential & $\begin{array}{l}\text { Daily values of } \\
\text { probability for infection } \\
(0-4)\end{array}$ & $\begin{array}{l}\text { Climatic model - } \\
\text { Reis et al. (2004) }\end{array}$ \\
\hline 9 & Non-linear regression & $E-R P$ & Infection potential & $\begin{array}{l}\text { Daily infection } \\
\text { efficiency }(0-100)\end{array}$ & $\begin{array}{l}\text { Canteri et al. } \\
\text { (2004) }\end{array}$ \\
\hline 10 & Neural networks & E - RP & $\begin{array}{l}\text { Epidemic } \\
\text { potential }\end{array}$ & $\begin{array}{l}\text { Daily disease severity } \\
(\%)\end{array}$ & $\begin{array}{l}\text { Batchelor et al. } \\
\text { (1997) }\end{array}$ \\
\hline 11 & $\begin{array}{l}\text { Fuzzy logic }+ \text { non linear } \\
\text { regression }\end{array}$ & $\mathrm{E}-\mathrm{RA}, \mathrm{RP}$ & $\begin{array}{l}\text { Epidemic } \\
\text { potential }\end{array}$ & $\begin{array}{l}\text { Apparent infection rate } \\
\text { and disease severity } \\
\text { progress }(\%)\end{array}$ & $\begin{array}{l}\text { FLAIR }^{7} \\
\text { Kim et al. (2005) }\end{array}$ \\
\hline 12 & Linear regression & $\mathrm{E}-\mathrm{RA}, \mathrm{RP}$ & $\begin{array}{l}\text { Epidemic } \\
\text { potential }\end{array}$ & $\begin{array}{l}\text { Final or maximum } \\
\text { disease severity }(\%)\end{array}$ & $\begin{array}{l}\text { Del Ponte et al. } \\
(2006)\end{array}$ \\
\hline
\end{tabular}

1. $\mathrm{S}=$ Simulation, $\mathrm{E}=$ Empirical

2. $\mathrm{RA}=$ Risk assessment, $\mathrm{RP}=$ Risk prediction

3. Soybean Rust Aerobiology Prediction System

4 NOAA ARL HYSPLIT 4 (Hybrid Single-Particle Lagrangian Integrated Trajectory)

5. North American Plant Disease Forecast Center

6. CLIMEX computer model (Southerst \& Maywald, 1985).

7. Fuzzy Logic Apparent Infection Rate

(models 4-6, Table 1) and, in some cases, the subsequent host infection and colonization after entry (model 7, Table 1).

\section{Epidemiological models}

The first ASR simulation model (SOYRUST) (Yang et al., 1991a) was developed and validated with data from literature and sequentially-planted field experiments conducted at the Asian Vegetable Research and Development Center (AVRDC) in southern Taiwan in the early $80 \mathrm{~s}$. SOYRUST is a process-driven computer model that simulates daily increase of disease severity in two soybean varieties (Yang et al., 1991a). Rate variables estimate leaf area development and disease components, including infection, latent period and uredinia senescence. While infection rate is influenced by leaf wetness duration and temperature, latent period and uredinia senescence are a function of temperature. Basically, the model reflects the environmental effect on the epidemic cycle to predict epidemic development in daily steps. Local model validation was performed using three soybean growing seasons within a single year and showed that the model was accurate in simulating the disease, with the primary model fluctuations due to differences in seasonal temperature. Prediction accuracy was reduced if growing season temperatures were either warmer or colder than regular growing season.

SOYRUST was further linked to a soybean model, SOYGRO, in order to simulate disease effects in the soybean yield and assess potential crop losses in some locations in the United States (Yang et al., 1991b). The link between these two models is through the estimated disease severity 
in SOYRUST, which is used to update the "Leaf Area" variable estimated by SOYGRO. From the estimated disease severity, a measure of the corrected leaf area variable is obtained. This variable directly affects plant photosynthesis and, consequently, the yield. At the end of the simulation, the model generates disease progress curves and final yield in the presence or absence of ASR.

More recently, Pivonia \& Yang (2006) adjusted a general disease model to predict onset time for four other rust diseases than ASR (two from corn and two from wheat) by examining the temperature effect at the initial stages of an epidemic, in order to assess establishment potential by the estimation of daily increase of infection units (model 2, Table 1) in susceptible hosts during the exponential phase of an epidemic. The general disease model components are infection efficiency, latent period, infectious period, number of spores produced per lesion and proportion of spores landing on a potential infection site (Gumpert et al., 1987). In Pivonia and Yang's model, the initial influx values of spores from an external inoculum source were based on literature data for other rusts. This model was used for risk assessment through the calculation of the number of infections and rate of disease increase amongst the five rust pathogens. Using climatology data for specific locations within the United States (for southern to northern locations), they observed that a longer period of time would be required for ASR to increase from trace to visual detection levels in the field. The authors speculated that in the southern United States, the low temperatures in May and June would limit disease development, causing a delay in disease incipience in northern locations. The model assumes non-limiting moisture conditions for rust infections.

Since $P$. pachyrhizi is an obligate parasite, overwintering survival of the pathogen is critical for development of year-to-year epidemics. CLIMEX is a computer model used to assess climatic suitability for biological processes (Southerst \& Maywald, 1985). The third model presented was developed by Pivonia \& Yang (2004), who adjusted the biological parameters in CLIMEX to integrate information on the response of $P$. pachyrhizi to environmental conditions in order to determine stressfree zones for year-round survival of $P$. pachyrhizi around the world. Parameters for the estimation of cold, warm or moisture stresses were defined based on literature data. Threshold values for cold and warm stresses were defined as 11 and $34{ }^{\circ} \mathrm{C}$, respectively. Stress indices take into account the continuous occurrence of those values around the stress level. For example, $100 \%$ of cold stress would accumulate after 9 to 10 weeks with mean minimum temperature of $7{ }^{\circ} \mathrm{C}$ level, and $100 \%$ of warm stress would be calculated after 9 to 10 sequential weeks of constant temperature approximately $40{ }^{\circ} \mathrm{C}$. Moisture stress would not occur if weekly precipitation was as low as $10 \mathrm{~mm}$. If precipitation was lower than 10 $\mathrm{mm}$, a procedure was created to take relative humidity into account. When relative humidity was $\geq 90 \%$ for 6 hours or more in a single day, moisture stress did not occur. A final equation in CLIMEX calculates a stress-free index ( 0 to 1 ) for a single location, taking into account the three stress indices. Values close to 1 suggest higher chance for yearround spore survival, which means no stress conditions developed in most of years. The results allowed determining worldwide regions where year-round inoculum survival would be most likely and others where ASR epidemics would depend on primary inoculum originating from long distances (overwintering sources).

\section{Aerobiological models}

Aerobiology is the study of biological processes involved in the movement of microorganisms in the atmosphere from one geographical location to another (Gregory, 1973). Given that spores of P. pachyrhizi are capable of long-distance travel via air currents, aerobiological models have been proposed for risk assessment and seasonal ASR prediction (Isard et al., 2005, Pan et al., 2006).

The first ASR aerobiological model to describe is a climate-dispersion integrated model system developed for simulating long-distance and long-term transportation of $P$. pachyrhizi using climate forecast over one month in advance (Pan et al., 2006). The application is based on the atmospheric transport model NOAA ARL HYSPLIT_4 (HYSPLIT - Hybrid Single-Particle Lagrangian Integrated Trajectory) (NOAA, 2006). The HYSPLIT model simulates single trajectories of air parcels, dispersal, concentration and deposition of particles, originating from a source geographical location and time of year. In Pan and collaborators' model, parameters for strength of inoculum source, spore production, survival and deposition were mechanistic and empirically estimated, based on the current knowledge on the system and physical principals (Pan et al., 2006). The model accounts for the dispersal of spores at multiple altitudes in the lower atmosphere and incorporates both dry and wet spore deposition processes. To predict spore dissemination months ahead, the model used climate prediction data from the Experimental Climate Prediction Center (ECPC) of the Scripps Institution of Oceanography. This climate prediction data was fed into the Pennsylvania State University/National Center for Atmospheric Research mesoscale model (MM5) that estimates meteorological variables to input into the NOAA ARL HYSPLIT_4 (NOAA, 2006). The first application of this ASR aerobiological model was to hindcast likely dispersal of $P$. pachyrhizi spores from sources in Africa into South America in 2002 (Pan et al., 2004) and to forecast dispersal from central to northern soybean production regions in South America during March 2004. In July 2004, a confirmed source of $P$. pachyrhizi in Colombia was used to predict movement of spores to North America using climate forecast data. Spore dispersal maps generated by the model showed likely spread of spores to the southern United States later in the season, which were confirmed by the findings of the disease in November 2004, in several locations in gulf coastal states (Pan et al., 2006). During the 2005 soybean growing season in the United States, the model was used 
to predict the likeliest within-season movement of spores from confirmed locations of Asian soybean rust infections in the southern states. In this application, the model was run on a weekly basis with forecasted weather data to predict likely movement and concentration of spores into northern regions of the country, as part of a framework to predict the seasonal risk of soybean rust in that year (Pan et al., 2005, 2006). The quasi-operational prediction in the 2005 growing season further indicated that the model could capture the general pattern of disease spread in the southeastern states. The month-long prediction of spore movement was based on the emerging seasonal forecast techniques that predict mean conditions (or climate), rather than day-to-day weather (Pan et al., 2006)

Modifications to the ASR HYSPLIT-based model used by Pan et al. (2006) were made using a statistical approach which analyzed 7 years of climate data in order to assess the potential spread of viable spores arising in a certain fixed number of locations and periods of time within the United States, as part of a risk assessment framework (Kim et al., 2005). The authors adjusted components in the basic aerobiological model to simulate survival of spores during transport and the potential entry of viable spores in a region (model 4, Table 1). This model ran using hourly meteorological data from the years 1997 to 2003 in order to calculate a combined availability index (CAI). The higher the index for a region, the greater the climatic potential for spore availability. An index of 7 indicates deposition of viable spores during all years in the simulation (Figure 1). The authors suggested that there is the potential for soybean rust spore dispersal over long distances in some years; however, the frequency and spatial distribution of spores was quite variable across years.

A third application was made using the HYSPLIT model to predict ASR risks in the United States during the 2005 growing season (NAPDFC, 2005). In this, each prediction included a description of the factors pertinent to the disease status, a general outlook that assessed the risk of disease development, and a map showing the spore-laden wind flowing away from an active source or source region (i.e., a cluster of closely-grouped counties) using multiple, centrally-located trajectories. To estimate the risk of ASR, researchers combined biological and meteorological elements into a qualitative evaluation of the risk of disease development associated with one or a group of sources. The forecasting procedure that defines disease "threats" and "risks" follows the model proposed to forecast tobacco blue mold, in which the meaning is described elsewhere (Main et al., 2001). The model allowed then the prediction of entry and establishment potential by estimating qualitative risks (model 6, Table 1).

The last ASR aerobiological model to describe is called SRAPS (Soybean Rust Aerobiology Prediction System) and is an advance on the other models of this kind since it aims to simulate the transportation process of airborne inoculum and the further disease establishment and

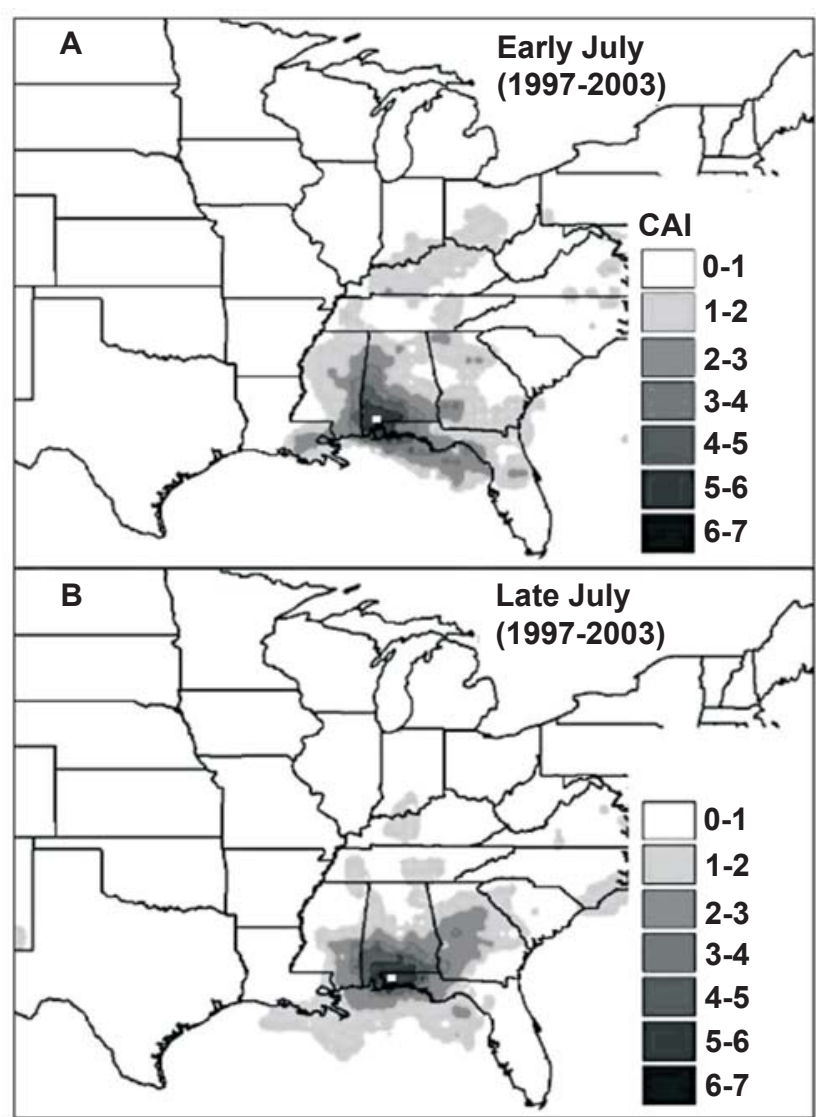

FIG. 1 - Computer simulation of historical weather data (19972003) for potential deposition areas for Phakopsora pachyrhizi during two 15-day period in the month of July (A and B) produced from southeastern Alabama if a large amount of spores is produced there. Grayscale code is the relative frequency of spore travels expressed as CAI (combined availability index), a qualitative index (0-7) for possibility of spore deposition. White square indicates area of spore's source. Adapted from Yang et al., (2005).

spread using a geographical perspective (model 7, Table 1). The model is modular and includes most of the basic stages of the aerobiological processes, such as: spore production, release and escape from canopy, spore mortality by exposure to solar radiation during atmospheric transport, and wet deposition of spores at target regions. In its application, the model requires input of information regarding the geographical location of inoculum. Preliminary versions of SRAPS model have been previously used to assess the potential pathways by hindcasting spore movement from Africa into South America and from South into North America (Isard et al., 2004). For SRAPS applications in risk prediction confined to North America, the model is linked to a geographical information system and is run on a $10 \times 10 \mathrm{~km}$ grid. In each grid cell, a degree-day based model estimates host development (soybean and alternative hosts) to estimate availability of host tissues for infection. Disease progress calculation is then initiated once spore deposition is estimated within a grid cell that has susceptible hosts. Parameters, 
details and model application are described elsewhere (Isard et al., 2004, 2005). In the 2005 growing season, the system was run through the Internet (USDA APHIS, 2005). A nationwide network of sentinel plots was established and intensively monitored to inform the geographic distribution of the early season pathogen in southern soybean regions in the United States. Each day, SRAPS-generated maps showing deposition of spores, phenological development of soybean and kudzu, and disease progression estimated on these hosts were available to extension specialists as a basis for commentaries and regional recommendations (Isard et al., 2005).

\section{Empirical models}

Six empirical models are described here, and they were separated into three kinds according to epidemic component estimated: suitability or critical periods for infection, disease progress, or maximum disease severity levels (models 8 to 13, Table 1). Such empirical models were obtained using modeling techniques such as linear and non-linear regression, neural networks and fuzzy logic.

\section{Suitability or critical periods for infection}

The two empirical models that predict the suitability or critical periods of infection for ASR were developed and applied in Brazil. They basically follow the principles of several models that were developed for other foliar diseases (Krause et al., 1975, Lalancete et al., 1988, Evans et al., 1992).

Reis et al. (2004) proposed a climatic model to predict a daily value for the probability of infection by $P$. pachyrhizi based on literature data regarding the interaction of leaf wetness duration-mean temperature during period of wetness and infection (Melching et al., 1989). Reis et al. (2004) reanalyzed the original data in order to obtain a surface response model that estimates the intensity of lesions (lesions. $\mathrm{cm}^{-1}$ ). The authors developed a "table of critical periods" for daily values for probability of infection (DVPI), which are a function of the number of lesions predicted to develop in a single day according to leaf wetness duration and temperature. In its application, the climatic model was input into a computerized weather station equipped with electronic sensors that measured temperature and leaf wetness every 15 minutes (Aura One. Quanta Agro, Passo Fundo - RS). The device is then placed within or near a field, from which DVPI are calculated and an alert will then be shown on the display whenever cumulative DVPI (CDVPI) reaches a defined threshold. The system has been validated across soybean regions in Brazil to determine the correlations between CDVPI and the disease's onset and incidence progress - proportion of leaves infected over time. In the validation experiments, a trap plot $(10 \times 10 \mathrm{~m})$ was sown 20 days prior to the production field in order to detect the presence of local inoculum. Recordings of leaf wetness and mean temperature during the wet period were initiated by the time first leaves emerge and the trap plot was monitored twice a week. Preliminary results indicated that there was a high probability for disease occurrence when CVDPI values reached values from 30 to 45 across the locations. At Pereiras municipality, São Paulo State, disease onset occurred when CDVPI reached 30 units (Figure 2). For Primavera do Leste, Mato Grosso State and Londrina, Paraná State, disease onset was observed when CVDPI reached 32 and 45, respectively (data not shown). Efforts are underway to define threshold values for specific regions in order to time fungicide sprayings according to weather suitability for Asian soybean rust.

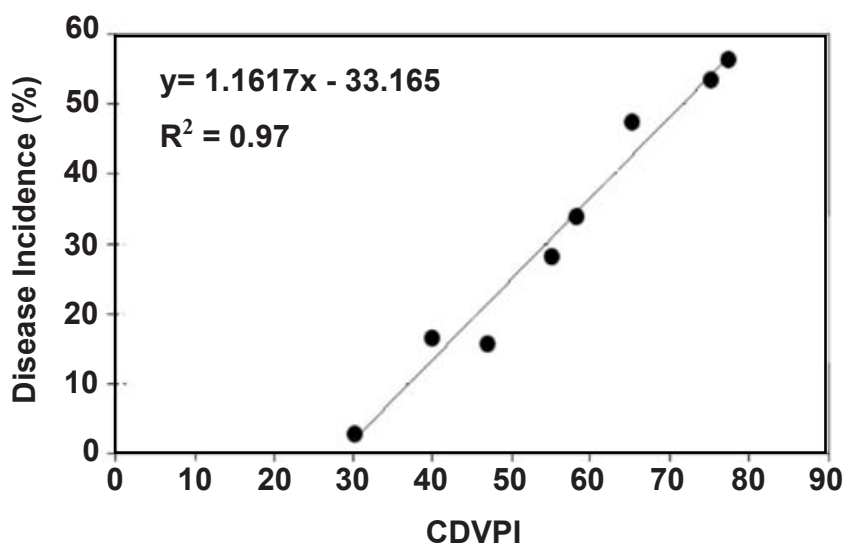

FIG. 2 - Relationship between Asian soybean rust incidence on leaflets and cumulative daily values probability for infection (CDVPI) for the location of Pereiras, São Paulo State, Brazil. Disease onset occurred when CDVPI accumulated 30 units. Source: Reis et al. (data not published).

The other Brazilian model follows a similar methodology. Canteri et al. (2004) used epidemiological data observed by Marchetti et al. (1976) which they translated into a mathematical function that estimates relative intensity of infection as a function of the number of hours of leaf wetness and mean temperature recorded during the wet period. The infection-based model was developed using non-linear regression approaches that combined the Beta function to model temperature response and Richard's model with four parameters to model the response to leaf wetness duration. The model was used in a risk assessment study with climatology data from 6 years to map epidemic potential in Paraná's soybean regions (Canteri et al., 2005). In the risk prediction application for that State, the model is input daily with meteorological (temperature and relative humidity over $90 \%$ as a surrogate for leaf wetness) and altitude data, to generate state-wide risk prediction maps for favorability of infection by $P$. pachyrhizi for Paraná State during the 2004/05 and 2005/06 growing seasons (Fundação $\mathrm{ABC}, 2006$ ) (Figure 3). In this prediction system, risk maps are generated daily and results are summarized for periods of a week or a month to map regions where a higher climatic favorability has been predicted. Further adjustments in the system will include the use of the new information obtained 


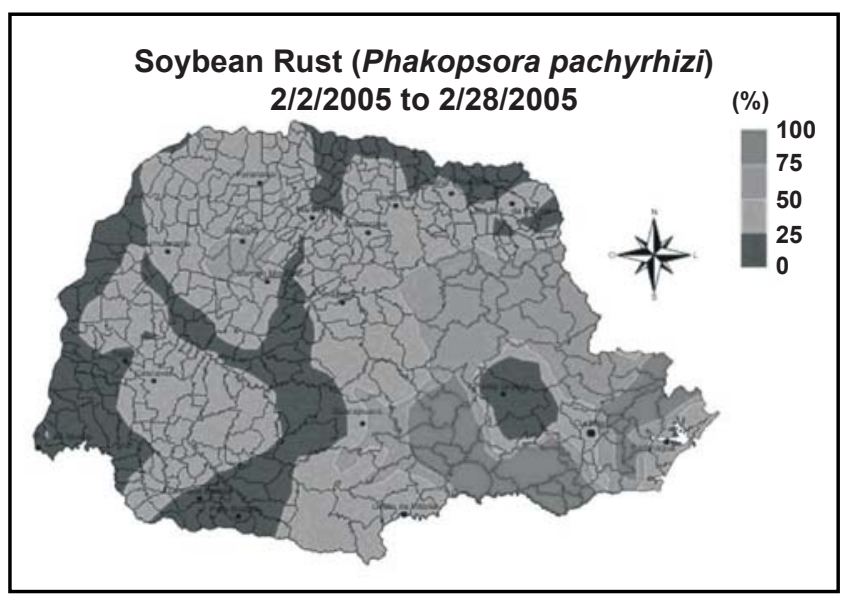

FIG. 3 - Risk map for Asian soybean rust in Paraná State, Brazil, generated by using a prediction model that uses temperature and leaf wetness duration to predict climatic favorability for infection. The map above summarizes the frequency of favorable events for infection during the month of February 2005. Adapted from Fundação ABC (2005).

in recent studies in Brazil for the effect of temperature and leaf wetness duration on infection (Alves et al., 2006).

\section{Disease development}

Two other techniques have been applied to develop ASR models using the extensive disease data from Taiwan, apart from the SOYRUST simulation model. They are neural networks and fuzzy logic.

Batchelor et al. (1997) developed a neural network model using the data from epidemics recorded in growing seasons in 1980 (model training) and then validated that model with data from 1981 growing seasons in that country in order to predict ASR severity in a single day (model 10, Table 1). Neural networks are sophisticated pattern recognition systems capable of learning relationships in patterns of information and, once trained, they can be used to classify new disease patterns according to the knowledge on the existing patterns (Ripley, 1996). For ASR, Batchelor et al. created 7 input variables: 1) planting date, 2) days to maturation, 3) first day the disease was observed, 4) age of plants on the evaluation date, 5) cumulative days of relative humidity greater than $90 \%, 6$ ) cumulative degreedays for rust development, and 7) cumulative degree-days for crop development. Two models, using three- or fourinput variables, respectively, had the best results with a coefficient of determination $\left(R^{2}\right)$ of 0.85 . The three-input variable model had the lowest mean prediction error and a higher coefficient of determination. The predictor variables were: (i) day disease was observed, (ii) cumulative degreeday for rust development and (iii) cumulative degree-day for soybean development. For the four-variable model, an additional variable, cumulative daily relative humidity over $90 \%$, was added to the three-variable model; however, no increase in prediction accuracy was observed. Using the
1981 Asian soybean rust data (model validation), $84 \%$ of the cases were within deviations (observed minus predicted) of \pm $20 \%$, and $54 \%$ of the cases were within $\pm 10 \%$ actual disease severity. The authors suggested the potential application of neural networks for predicting Asian soybean rust, given that their results were comparable to the SOYRUST model and that the variables used in the neural network model were based on degree-days, which have a biological meaning, -ie. severity levels are expressed as a function of host, pathogen, environment and time.

Kim et al. (2005) developed a fuzzy logic-based model using the Taiwan data to estimate the apparent infection rate, an input variable found in the logistic population growth model (van der Plank, 1963). Their model, named FLAIR (Fuzzy Logic Apparent Infection Rate), used a dataset for training some functions and decision rules within the context of fuzzy logic. Twelve decision rules were determined using the previous knowledge regarding the epidemiological knowledge of Asian soybean rust. As an example, two rules were defined in the following manner: 1) "if mean night-time temperature is very low, then apparent infection rate is very low", 2) "if maximum daily temperature is high, then the apparent infection rate is low". A fuzzy logic model describes the variables and their states in natural language terminology, such as "very low" and "very high". Through a process called "fuzzyfication", a quantitative value is included in the system and converted into the linguistic term. Specific details are well explained in Kim et al. (2005). In the model validation, the authors assumed that initial infection occurred 14 days after planting and initial severity values were heuristically estimated for each case in the validation dataset. The authors found that in cases when mean seasonal temperature was higher than $25{ }^{\circ} \mathrm{C}$, or lower than $20{ }^{\circ} \mathrm{C}$, Asian soybean rust epidemics deviated from a logistic pattern, resulting in failure of the model to correctly simulate disease severity during those periods. The rules created in this model did not use measurements of leaf wetness, but night-time temperature as a surrogate variable. This variable did not seem to affect the model performance, which was not much of a surprise given that moisture was not a limiting factor for epidemics in Taiwanese experiments (Yang et al., 1991, Batchelor et al., 1997). The authors suggested that a population dynamics model using estimations of the apparent infection rate by the FLAIR model satisfactorily simulated disease progress as $85 \%$ of disease variation in the validation dataset was explained, and this approach showed potential for disease prediction, conditional on the availability of a model that accurately estimates initial disease severity levels (Kim et al., 2005).

\section{Maximum disease severity}

The last model to describe was developed by Del Ponte et al. (2006) who used linear regression to examine the relationship between final or maximum ASR disease severity field epidemics and daily weather variables recorded 
during epidemic development after ASR was detected. They examined data from 34 naturally occurring epidemics in experimental plots that were located at 21 sites from southern to northern soybean regions in Brazil over three growing seasons (2002/03 to 2004/05). The authors found that use of a rainfall variable best predicted final ASR severity, whereas temperature variables had poor predictive ability (Figure 4). The rainfall models explained 85 to $93 \%$ of the variation in maximum disease severity. Two rainfall models, the first a second-order linear model using only accumulated rainfall for the 30-day period following disease detection, and the second, a first-order linear response model that used the same variable and also the number of rainy days for the same period, had highest $R^{2}$, as well as lowest prediction errors. The first-order linear model tended to overestimate when actual disease severity was $<30 \%$, while the secondorder linear model had predictions with lower deviations from the actual disease severity. Low values for maximum disease severity were found for locations in southern regions of Brazil (latitude $>23^{\circ}$ ), where relatively longer dry periods were recorded, and where minimum temperature was lower during the growing season, compared to northern locations. This work showed a capacity for predicting epidemic potential, where the epidemic prediction is based on a function of rainfall over a 30-day period following disease detection. The results observed by Del Ponte et al. (2006) on the use of rainfall to predict soybean rust epidemics confirmed previous reports from China, where an empirical model based on the number of rainy days and accumulated rainfall for the month of September (using 7 years of epidemic data) was developed to predict a soybean rust index at one single location in Wuhan province (Tan et al., 1996).

The rainfall models developed by Del Ponte et al. (2006) have been applied in both risk assessment and prediction studies. For the former, the model was used to determine the seasonal epidemic potential for twenty specific locations in soybean regions in the United States. Fifty years of weather data were used to determine the frequency of moderate $(>25 \%$ disease severity) and severe $(>50 \%$ disease severity) epidemics across the locations, for two scenarios of disease detection time during the growing season (late June or late July). Results, using climate data for July and August, considered the most critical months, indicated a distinct climatic suitability for epidemic across different regions. Rainfall patterns in the main soybean regions (northern locations) seem not to be suitable for severe epidemics, such as those observed in central-western Brazil, although the disease can develop to light and moderate levels every year if inoculum is available early to mid-season, a condition that may not happen every year, because spores need to migrate from southern to northern locations (Del Ponte et al., 2005). Yang (2006) affirmed that such information is very important for policy makers; for example, if epidemic levels of concern have a frequency of one-in-eight or ten years, which was the case for some locations in the risk assessment study, then Asian soybean rust may not be considered a major production concern for the region.

During the 2005 season in the United States, the rainfall models developed by Del Ponte and collaborators were used for seasonal and large-scale predictions of soybean rust, in combination with results from an aerobiological model (Pan et al., 2006). Briefly, rainfall information from the past 15 days (NOAA, 2005) was combined with the 15day rain forecast (giving a cumulative 30 -day period) from MM5 models and used to produce risk maps for suitability of climate conditions in the United States to determine regions where it is more favorable for soybean rust to develop if the disease was found (Pan et al., 2005). A risk interpretation was made by specialists using information from maps of spore concentration and climatic suitability (Figure 5).
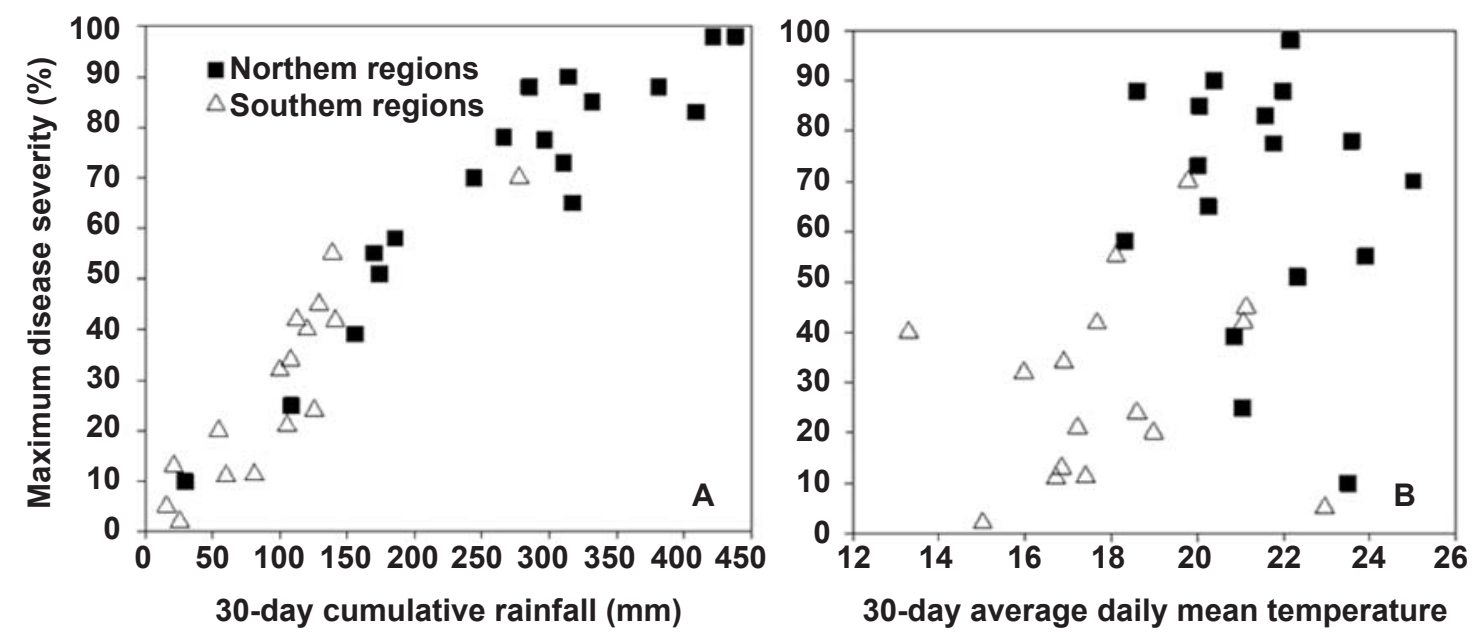

FIG 4 - A. Relationship between 30-day accumulated rainfall; B. and average daily mean temperature, following soybean rust detection and estimated final or maximum disease severity at maturity stages of soybean observed in 34 natural epidemics in 21 locations from 2003 a 2005 in Brazil. Adapted from Del Ponte et al. (2006). 
Risk information was made available to plant pathologists, specialists and risk interpretations to the public during the season (Del Ponte \& Yang, 2005).

\section{Uncertainties and challenges for the future}

In spite of the great efforts to increase our understanding of the Asian soybean rust pathosystem, there are still numerous uncertainties and difficulties that must be overcome in order to make the most accurate risk assessment and risk predictions. They relate mainly to inoculum availability, confidence in weather and climatic data, gaps in epidemiological knowledge, and built-in limitations to a model and its validation. Although it seems plausible to extensively monitor early-season inoculum using trap plots and intensive disease scouting, it is still extremely difficult to dimension the actual number of inoculum sources across the regions in order to input these into aerobiological models. For example, within some locations several alternative hosts may harbor P. pachyrhizi spores, and many of the events associated with either local or long-distance spore dispersal (release, transport, survival and viability) are not satisfactorily understood. Further research is necessary to understand factors such as solar radiation, ultra-violet light, temperature and rain and how they may affect aerobiological processes. Recent studies on the mortality of $P$. pachyrhizi spore by the effect of solar radiation are very useful for improving predictions of spore movement based on aerobiological models (Isard et al., 2006). There is also a definite need for an improved understanding of the role of alternative hosts such as kudzu. Kudzu is a widely distributed weed across southern United States, and there is an inconsistency in the relative susceptibility of kudzu to P. pachyrhizi, the reasons for which are still not fully understood. Also, increased understanding of environmental and landscape factors related to inoculum build-up and further local or long-distance disease spread in a region requires further investigation and seems to be one of the most critical pieces of information, especially for models that predict risk in regions where inoculum cannot survive or was not found. To overcome problems related to inoculum uncertainties, it remains crucial to monitor the inoculum by the use of spore samplers or trap plots. Besides the usefulness for alerting researchers to the presence of inoculum, the extensive data on inoculum monitoring will surely help to validate current models.

Regarding empirical infection-based models that take into account only the environmental effect on one component of an epidemic, a potential problem is that a high climatic favorability for infection may be estimated when inoculum is absent. However, further validation of such models will demonstrate the usefulness of the prediction systems at the field level for regions where inoculum is not limiting. A true seasonal disease risk prediction should be based on weather and climate forecasts; however, weather-related variables, such as leaf wetness duration, are difficult to estimate from weather forecasts. Moreover, spatial variations and biased

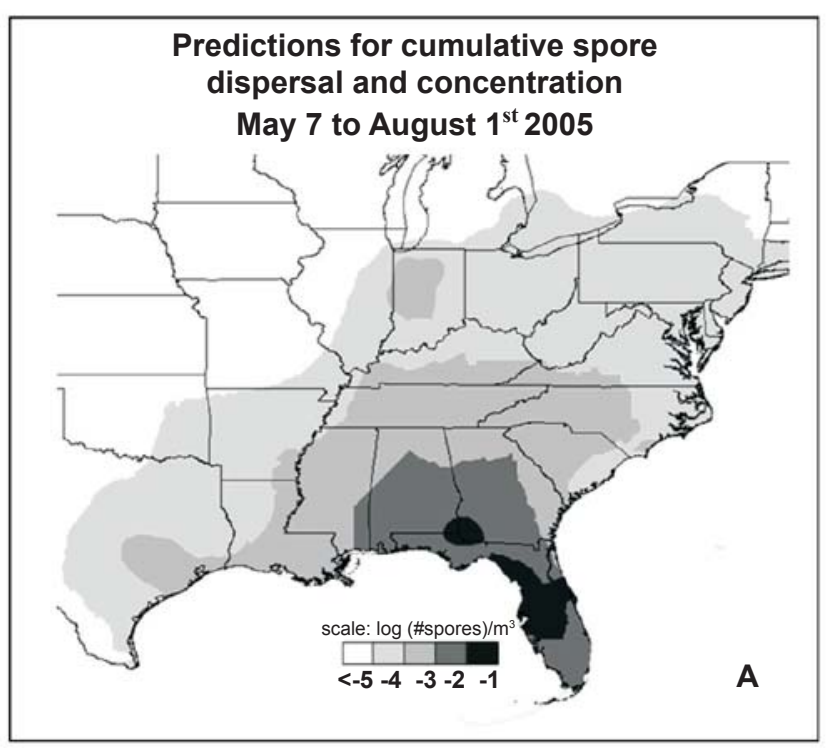

Climatic suitability for soybean rust epidemics June 18 to July 172005

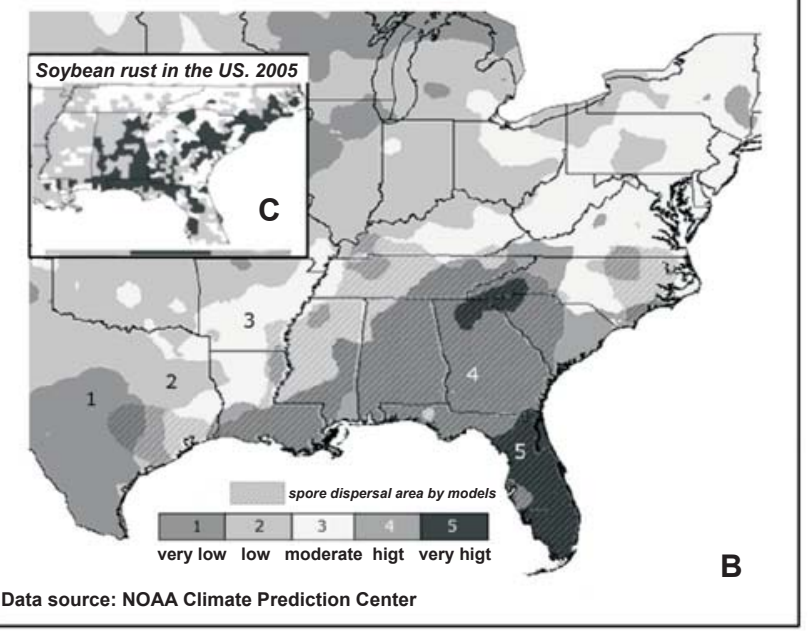

FIG. 5 - Seasonal risk prediction framework for Asian soybean rust epidemics in the United States, 2005 year. A. Maps for spore concentration in the air predicted for over 2 month period; B. Maps for climatic suitability for soybean rust epidemics during a 30-day period based on a rain model; C. Risk for disease establishment was estimated higher for regions where both higher climatic favorability and higher spore concentration was predicted (or an inoculum source was reported in a region). Soybean rust was confined to southern United States by the end of 2005 season (source: PIPE - http://www.sbrusa.net).

estimations of the actual leaf wetness duration, using sensors or empirical and physical models, may affect the accuracy of the prediction. Numerical long-term forecast (one to four weeks) for precipitation by mesoscale models are being tested to warn of regional disease outbreaks. Such rainfall models estimating monthly periods of weather favorability may indicate regions at higher risk of epidemic build-up, since there is information of 
disease onset from regional surveys. Interpretations of rainfall model predictions should be made from a higher spatial scale, representing an estimated risk for regional average conditions, and not from field level assessments, although the model can be used at the farm level once there is information on rainfall for the site.

When selecting and evaluating models to input into a risk prediction or assessment framework, one needs to know model details, how they were constructed, variables needed and on which scale and in which locations they should be applied to minimize prediction error. Fundamentally, empirical models developed with data from one region should be tested and validated for another region, before implementing broad use. However, a model constructed from a dataset collected over a large geographic region for a longer period of time would provide more reliable prediction, and so could be used in risk assessment of an exotic and new disease to an area. This assessment can be made for single or combined components, such as entry, establishment, epidemic and loss potential (Yang, 2006). Model validation may be, in turn, more critical for seasonal risk prediction at lower spatial and time scales when information will be used for the farmer's decision.

According to Isard et al. (2005), the use of aerobiological models to forecast aerial movement of an invasive species is in its infancy and will require the integration of biological knowledge, monitoring techniques and information technology. The efforts and advances in the development of a general aerobiological framework will be important to predict invasive species (including Asian soybean rust), enabling a rapid and comprehensive response to complex processes. Some of the limitations of such complex simulation models may be related to error amplification if inaccurate estimations are made for single components. For example, wrong estimations for spore strength and dispersal from a source by aerobiological models may lead to over-predicting infections in a target region. However, an aerobiological framework, besides prediction application, is considered an important tool to identify knowledge gaps and point toward the future epidemiological research that might lead to more accurate predictions. Moreover, as observed, $P$. pachyrhizi spore data may become available in the coming years, Pan et al. (2006) showed how validation of aerobiological models against actual spore concentration would improve model formulations, serving as a useful guide for early warning and detection of ASR, especially for regions where primary inoculum comes from distant regions.

In spite of the uncertainties, incredible advances in science and the use of cutting-edge technologies for plant disease prediction have been made in recent years to develop, enhance and apply models to predict and assess the risk of ASR. Advances such as aerobiological models and use of climate forecasts would not have been possible without the integration of a multi-disciplinary team of researchers, including plant pathologists, meteorologists, climatologists and computer specialists. Efforts for monitoring disease patterns (over years), spore trapping and further biological research will continue to provide valuable information for enhancing models that are currently being applied in the leading soybean-producing countries - the United States and Brazil. Although the situation in the two countries is contrasting in terms of the impact of this disease on production, the previous and ongoing collaborative efforts among researchers and modelers from both countries have been of extreme value. Brazil provides a unique situation to observe disease patterns every year under very distinct conditions, and it can learn from North American experience in risk assessment and prediction to improve current models. Such interactions and information will help to keep improving our understanding of the factors affecting epidemics from field to continental scale, in order to deliver more realistic information about ASR risks to the various receivers.

\section{ACKNOWLEDGEMENTS}

We appreciate the critical review of this manuscript and suggestions given by Paul Esker, a Postdoctoral Research Fellow of the National Science Foundation on Biological Informatics and Francisco F. Laranjeira.

\section{REFERENCES}

ALVES, S.A.M., FURTADO, G.Q. \& BERGAMIN FILHO, A. Influência das condições climáticas sobre a ferrugem da soja. In: Zambolim, L. (Org.). Ferrugem Asiática da Soja, Visconde do Rio Branco MG. Suprema Gráfica e Editora. 2006. pp. 37-59.

ALVES, S.A.M., FURTADO, G.Q., GODOY, C.V. \& BERGAMIN FILHO, A. Influência da temperatura no período latente da ferrugem asiática da soja. Summa Phytopathologica 32:S71. 2006. (Resumo)

BATCHELOR, W.D., YANG, X.B. \& TSCHANZ, A.T. Development of a neural network for soybean rust epidemics. Transactions of the American Society of Agricultural Engineers 40:247-252. 1997.

BROMFIELD, K.R. Soybean rust: some considerations relevant to threat analysis. Protection Ecology 2:251-257. 1980.

BROMFIELD, K.R. Soybean Rust. Saint Paul MN. APS Press. Monograph no. 11. 1984.

CALDWELl, P.M., NUNKUMAR, A., PRETORIUS, Z.A. \& FERNANDES, J.M.C. Development of Phakopsora pachyrhizi at different temperatures, relative humidities and leaf wetness duration. Proceedings, 9th International Workshop on Plant Disease Epidemiology. Landerneau, France. 2005.

CANTERI, M.G., GODOY, C.V., DEL PONTE, E.M., FERNANDES, J.M.C. \& PAVAN, W. Aplicações da computação na fitopatologia. Revisão Anual de Patologia de Plantas, 12:243285. 2004.

CANTERI, M.G. Mapas de Risco de Epidemias. Fitopatologia 
Brasileira, 29 (suplemento):S27-S28. 2004.

CANTERI, M.G., CARAMORI, P., TSUKAHARA, R., SILVA, O.C., FARIA, R. \& GODOY, C.V. A system to map risk of infection by Phakopsora pachyrhizi for Parana State, Brazil. Phytopathology 95:S16. 2005 (Abstract)

DEL PONTE, E.M. \& YANG, X.B. Estratégias de modelaje para la predición e comunicación del riesgo de epidemias de la roya asiática de la soja. In: Popler, L.D. (Ed.) Roya Asiática de la Soja en América - El libro. Las Talitas, Tucumán, Estación Experimental Obispo Colombres. 2006. pp. 49-62.

DEL PONTE, E.M., GODOY, C.V., LI, X. \& YANG, X.B. Predicting severity of Asian soybean rust with empirical rainfall models. Phytopathology 96:797-803. 2006.

DEL PONTE, E.M., LI, X. \& YANG, X.B. Assessing the rainfall suitability of Asian soybean rust epidemics in the US soybean regions. Proceedings, National Soybean rust symposium, Nashville, TN, USA. . Online: http://www.plantmanagementnetwork.org/ infocenter/topic/soybeanrust/symposium/posters/06.asp. 2005.

DUTHIE, J.A. Models of the response of foliar parasites to the combined effects of temperature and duration of wetness. Phytopathology 87:1088-1095. 1997.

EVANS, K.J., NYQUIST, W.E. \& LATIN, R.X. A model based on temperature and leaf weatness duration for establishment of alternaria leaf blight of muskmelon. Phytopathology 82:890-895. 1992.

FUNDAÇÃO ABC. Sistema de informação de doenças da soja. Online: http://sid.fundacaoabc.org.br. 2006.

GREGORY, P.H. The Microbiology of the Atmosphere. New York NY. Wiley. 1973.

GUMPERT, F. M., GEIGER, H. H. \& STAHLE, U. A mathematical model of the epidemics in homogeneous and heterogeneous host stands. Zeitschrift Pflanzenkrankheiten Pflanzenschutz 94:206215. 1987.

ISARD S.A., MAIN, C.E., KEEVER, T., MAGAREY, R., REDLIN, S. \& RUSSO, J.M. Weather based Assessment of Soybean Rust Threat to North America: First Year Report to Aphis. US Department of Agriculture, Animal and Plant Health Inspection Service. Online: https://netfiles.uiuc.edu/ariatti/www/SBR/Rep_ 15Jul04.htm. 2004.

ISARD, S.A., GAGE, S.H., COMTOIS, P. \& RUSSO, J.M. Principles of the Atmospheric Pathway for Invasive Species Applied to Soybean Rust. Bioscience 55:851-861. 2005.

ISARD, S.A., DUFAULT, N.S., MILES, M.R., HARTMAN, G.L., RUSSO, J.M., DE WOLF, E.D. \& MOREL, W. The effect of solar irradiance on the mortality of Phakopsora pachyrhizi urediniospores. Plant Disease 90:941-945. 2006.

KIM, K.S., YANG, X.B., PAN, Z. \& PEREZ-HERNANDES, O. Simulation of spore trajectories to identify potential pathways of soybean rust in the United States. Phytopathology 95:S54. 2005a. (Abstract)

KIM, K.S., WANG, T.C. \& YANG, X.B. Simulation of apparent infection rate to predict severity of soybean rust using a fuzzy logic system. Phytopathology 95:1122-1131. 2005b.

KITANI, K. \& INOUE, Y. Studies on the soybean rust. Bull. Shikoku Agric. Exp. Stn. (Zentsuji, Japan) 5:319-342. 1960.

KOCHMAN, J.K. The effect of temperature on development of soybeans rust (Phakopsora pachyrhizi). Australian Journal of
Agricultural Research 30:273-277. 1979.

KOCHMAN, J.K. Soybean rust in Australia. In: Ford, R.E. \& Sinclair, J.B. (Eds.) Rust of Soybean - The problem and research needs. Manila, Philippines. International Agricultural Publications. 1977. pp. 44-48.

KRAUSE, R.A. \& MASSIE, L.B. Predictive systems: modern approaches to disease control. Annual Review of Phytopathology 13:31-47. 1975.

LALANCETTE, N., ELLIS, M.A. \& MADDEN, L.V. Development of an infection efficiency model for Plasmopara viticola on American Grape based on temperature and duration of leaf wetness. Phytopathology 78:794-800. 1988.

LEVY, C. Epidemiology and chemical control of soybean rust in southern Africa. Plant Disease 89:669-674. 2005.

MARCHETTI, M.A., MELCHING, J.S. \& BROMFIELD, K. R. The effects of temperature and dew period on germination and infection by urediospores of Phakopsora pachyrhizi. Phytopathology 66:461-463. 1976.

MELCHING, J.S., BROMFIELD, K.R. \& KINGSOLVER, C.H. Infection, colonization, and uredospore production on Wayne soybean by four cultures of Phakopsora pachyrhizi, the cause of soybean rust. Phytopathology 69:1262-1265. 1979.

MELCHING, J.S., DOWLER, W.M., KOOGLE, D.L. \& ROYER, M.H. Effects of duration, frequency, and temperature of leaf wetness periods on soybean rust. Plant Disease 73:117-122. 1989.

NAPDFC. North American Plant Disease Forecast Center. Soybean Rust Forecast Homepage. Online: http://www.ces.ncsu.edu/depts/ pp/soybeanrust/. 2006.

NOAA. National Oceanic and Atmospheric Administration. Atmospheric Research Laboratory. NOAA ARL HYSPLIT Model. Online: http://www.arl.noaa.gov/ready/hysplit4.html. 2006.

NOAA. National Oceanic and Atmospheric Administration. Climate Prediction Center. 2005. Online: http://www.cpc.noaa.gov

PAN, Z., PIVONIA, S., PASKEN, R., PIETROWICZ, J. \& YANG, X.B. Simulation of airborne dispersal potentials of soybean rust from Africa to South America and from South America to North America. Phytopathology 94:S90. 2004. (Abstract)

PAN, Z., XUE, L., DEL PONTE, E.M., ANDRADE, D., LI, X., PASKEN, R. \& YANG, X.B. Soybean rust dispersal prediction and analysis in the US for 2005 growing season. Proceedings, National Soybean rust symposium, Nashville, TN, USA. Online:

http://www.plantmanagementnetwork.org/infocenter/topic/ soybeanrust/symposium/posters/26.asp. 2005.

PAN, Z., YANG, X.B., PIVONIA, S., XUE, L., PASKEN, R. \& ROADS, J. Long-term prediction of soybean rust entry into the continental United States. Plant Disease 90:840-846. 2006.

PIVONIA, S. \& YANG, X.B. Assessment of potential year round establishment of soybean rust throughout the world. Plant Disease 88:523-529. 2004.

PIVONIA, S. \& YANG, X.B. Relating epidemic progress from a general disease model to seasonal appearance time of rusts in the United States: implications for soybean rust. Phytopathology 96:400-407. 2006.

REIS, E.M., SARTORI, A.F. \& CAMARA, R.K. Modelo climático para a previsão da ferrugem da soja. Summa Phytopathologica 
30:290-292. 2004.

RIPLEY, B.D. Pattern Recognition and Neural Networks. Cambridge. Cambridge University Press. 1996.

ROSSI, R.L. First report of Phakopsora pachyrhizi, the causal organism of soybean rust in the Province of Misiones, Argentina. Plant Disease 87:102. 2003.

SCHNEIDER, R.W., HOLIER, C.A., WHITAM, H.K., PALM, M.E., MCKEMY, J.M., HERNANDEZ, J.R., LEVY, L. \& DEVRIES-PATERSON, R. First Report of Soybean Rust Caused by Phakopsora pachyrhizi in the Continental United States. Plant Disease 89:774. 2005.

SINCLAIR, J.B. \& HARTMAN, G. L. Soybean diseases. In: Hartman, G.L., Sinclair, J.B. \& Rupe, J.C. (Eds.) Compendium of soybean diseases. 4 ed. Saint Paul MN. APS Press. 1999. pp. 3-4.

SOUTHERST, R.W. \& MAYWALD, G.F. A computerized system for matching climates in ecology. Agriculture, Ecosystems \& Environment 13:281-299. 1985.

TAN, Y.J., YU, Z. \& YANG, C.Y. Soybean rust. Beijing, China. China Agricultural Press. 1996.

TENG, P.S. A comparison of simulation approaches to epidemic modeling. Annual Review of Phytopathology 23:351-379. 1985.
TSCHANZ, A. T. Soybean rust epidemiology: Final report. Asian Vegetable Research and Development Center. 1984.

VAN DER PLANK, J.E. Plant diseases: epidemics and control. New York NY. Academic Press. 1963.

YANG, X.B. Risk assessment: concepts, development, and future opportunities. Plant Health Progress. doi:10.1094/PHP-2003-11-302-RV. 2003.

YANG, X.B., DOWLER, W.M. \& TSCHANZ, A.T. A simulation model for assessing soybean rust epidemics. Journal of Phytopathology 133:187-200. 1991a.

YANG, X.B., DOWLER, W.M. \& ROYER, M.H. Assessing the risk and potential impact of an exotic plant disease. Plant Disease 75:976-982. 1991b.

YANG, X.B., DEL PONTE, E.M. \& KIM, K.S. Soybean rust outlook - June 30. Integrated Crop Management 494(17):4. 2005.

YANG, X.B. Framework development in plant disease risk assessment and its application. European Journal of Plant Pathology 115:25-34. 2006.

YORINORI, J.T. Asiatic rust of soyabean (Phakopsora pachyrhizi): occurrence in Brazil and management strategies. Londrina PR. Embrapa Soja, Documentos 186. 2002. pp. 73-83. 